\title{
IRRIGATION SCHEDULE ON TABLE GRAPES BY STEM WATER POTENTIAL AND VAPOR PRESSURE DEFICIT ALLOWS TO OPTIMIZE WATER USE
}

\author{
PROGRAMAÇÃO DA IRRIGAÇÃO DE UVA DE MESA UTILIZANDO O POTENCIAL HÍDRICO \\ XILEMÁTICO E O DÉFICIT DE PRESSÃO DE VAPOR PERMITEM OPTIMIZAR O USO DA ÁGUA
}

\author{
Rodrigo Gálvez $^{1}$, R. Callejas ${ }^{2}$, G. Reginato ${ }^{2}$, M.C. Peppi ${ }^{2}$ \\ ${ }^{1}$ Centro de Estudios Agronómicos, Universidad de Chile. Rómulo J. Peña, Copiapó, Chile \\ ${ }^{2}$ Departamento de Producción Agrícola, Facultad Ciencias Agronómicas, Universidad de Chile, Av. Santa Rosa 11315, La Pintana, Santiago, \\ Chile \\ * Corresponding author: Tel: 56-2-978 5727, fax: 56-2-2978 5813, e-mail: mpeppi@uchile.cl
}

(Received 08.09.2014. Accepted 08.12.2014)

\section{SUMMARY}

This study tested the relationship between stem water potential $\left(\psi_{\text {stem }}\right)$ and vapor pressure deficit (VPD) in order to evaluate its use as reference for irrigation control of table grape (Vitis vinifera) cvs. Thompson Seedless and Redglobe. Two trials were carried out on consecutive seasons. In the first season the treatments consisted of four different irrigation regimes: T1, plants irrigated at $100 \%$ of ETc; T2, irrigated until fruit set the same as T1 but after fruit set every other time T1; T3, plants with no irrigation from fruit set to harvest; and T4, plants irrigated at $50 \%$ of ETc throughout the growing season. Vines from T1 always showed a higher $\psi_{\text {stem }}$ for a wide VPD range, therefore the $\psi_{\text {stem }}$ and VPD relationship was established using T1 vines, obtaining a logarithmic function with a high determination coefficient $\left(\mathrm{R}^{2}=0.85\right)$. The following season this relationship was used to control irrigation frequency on two table grape cvs. Irrigation started when vines had $20 \mathrm{~cm}$ shoots and then the irrigation amount was set to replenish $10 \%$ of soil available water. Trial 1 was conducted on cv. Thompson Seedless and consisted of two treatments: T1 plants irrigated to satisfy $100 \%$ ETc and T2 plants irrigated according to the previously obtained $\psi_{\text {stem }}$-VPD reference line. Trial 2 was established with Redglobe cv. plants using three treatments: T1 plants irrigated to satisfy $100 \%$ Etc; T2, plants irrigated the same as T1 but after fruit set every other time T1; and T3, plants irrigated according to the $\psi_{\text {stem }}$-VPD reference line previously obtained. Irrigation frequency determined using the $\psi_{\text {stem }}$-VPD relationship reduced total water volume compared to T1 on both trials, with no effects on yield or quality, showing the feasibility of using this relationship to control irrigation frequency.

\section{RESUMO}

Este trabalho incidiu na análise da relação entre o potencial hídrico xilemático $\left(\psi_{\text {stem }}\right)$ e o déficit de pressão de vapor (VPD), para utilizá-la como referência na programação de irrigação em uva de mesa (Vitis vinifera) das variedades Thompson Seedless e Redglobe. Foram realizados dois ensaios em temporadas consecutivas. Na primeira temporada os tratamentos consistiram em quatro regimes de irrigação: T1, plantas irrigadas com $100 \%$ de ETc; T2, plantas irrigadas igual ao T1 até a frutificação e depois uma vez a cada duas irrigações deT1: T3, plantas sem irrigação entre a frutificação e a colheita; e T4, plantas irrigadas com 50\% de ETc durante toda a temporada. As plantas de T1 apresentaram sempre valores mais altos de $\psi_{\text {stem }}$ para uma ampla gama de VPD, portanto, a relação $\psi_{\text {stem }}$ VPD foi estabelecida utilizando plantas de T1, obtendo uma função logarítmica com um alto coeficiente de determinação $\left(\left(\mathrm{R}^{2}=0.85\right)\right.$. Na subsequente temporada esta relação foi utilizada para controlar a frequência de irrigação em duas variedades de uva de mesa. A quantidade de irrigação foi estabelecida para repor $10 \%$ de humidade aproveitável. O ensaio 1 foi realizado na variedade Thompson Seedless e baseou-se em dois tratamentos: T1, plantas irrigadas para satisfazer $100 \%$ de ETc e T2 plantas irrigadas de acordo com a relação $\psi_{\text {stem }}$ VPD obtida previamente. O segundo ensaio foi realizado com plantas da variedade Redglobe, com três tratamentos: T1 plantas irrigadas para satisfazer $100 \%$ de ETc; T2, plantas irrigadas igual ao T1 até a frutificação e depois uma vez a cada duas irrigações de T1; e T3, plantas irrigadas de acordo com a curva de referência $\psi_{\text {stem }}$ VPD obtida previamente. A frequência de irrigação

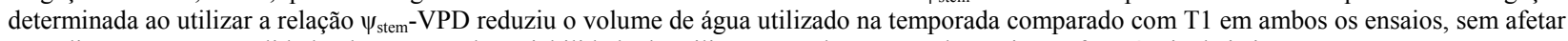
o rendimento nem a qualidade, demonstrando a viabilidade de utilizar esta relação para determinar a frequência de irrigação.

Key words: grape quality, irrigation control, irrigation frequency.

Palavras-chave: qualidade da uva, programação de irrigação, frequência de irrigação.

\section{INTRODUCTION}

Most methods used to estimate crop water requirements, including evapotranspiration (ET), are based on soil water content or climate factors (Howell and Meron, 2007), and the objective of irrigation scheduling is during the growing season to put back in the soil the water lost by ET (Shakel, 2011) and the

60

This is an Open Access article distributed under the terms of the Creative Commons Attribution License (http://creativecommons.org/licenses/by/4.0), which permits unrestricted use, distribution, and reproduction in any medium, provided the original work is properly cited. 
plant use of water. World water scarcity and increasing irrigation costs have emphasized the need for the development of methods to schedule and control irrigation in order to reduce water use, making crucial the evaluation of plant irrigation responses (Jones, 2004).

One physiological indicator that can be measured and used to determine plant water status is the stem water potential $\left(\psi_{\text {stem }}\right)$, which has been a good indicator on several species including grapevines (Naor et al., 1998; Choné et al., 2001; Williams and Araujo, 2002; Williams and Trout, 2005).

Grapevine $\psi_{\text {stem }}$ has been related to productive and physiological responses including stomatal conductance (Naor, 2000; Schultz, 2003; Shakel, 2007; Olivo et al., 2009), photosynthesis (Patakas et al., 2005), transpiration (Choné et al., 2001) and yield (Grimes and Williams, 1990; Marsal et al., 2008).

However, the plant water status is modified by environment conditions such as light, temperature and vapor pressure deficit (VPD). McCutchan and Shackel (1992) found a strong $\psi_{\text {stem }}$ VPD relationship on prune trees irrigated at $100 \% \mathrm{ET}$, obtaining a linear relationship they named "reference line" (RL) to be used as a tool for irrigation scheduling of prune and almond trees in California (Shackel et al., 1997). Likewise, Olivo et al. (2009) employed this methodology to generate a reference line for 'Tempranillo' winegrapes. The RL indicates nostressed plants with $\psi_{\text {stem }}$ values higher than RL and deficient irrigated plants when $\psi_{\text {stem }}$ values are lower than the RL.

Studies on table grapes have showed $\psi_{\text {stem }}$ variations depending on daily ambient factors (Smart, 1974; Van Zyl, 1987). Williams and Baeza (2007) working on different locations with wine and table grapes found that $\psi_{\text {stem }}$ presents more variation with VPD than air temperature. The RL tool has been very useful for irrigation scheduling on almond, prune and walnut trees among others (McCuthan and Shackel, 1992; Rosati et al., 2006; Shackel, 2011) and has shown some differences among species and cultivars. Similar water needs can be observed among table grapes but cultivars could show some differences, thus the objective of this study was to determine the feasibility of using a previously obtained RL for 'Thompson Seedless' and validate it for irrigation scheduling on the same cultivar and on 'Redglobe'.

\section{MATERIAL AND METHODS}

\section{Plant Material}

The trials were conducted during the 2007-2008 and 2008-2009 seasons, between fruit set and harvest, on commercial table grape vineyards (Vitis vinifera L.), located in El Tránsito, Huasco, Atacama Region,

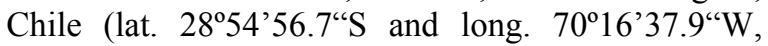
elevation $1195 \mathrm{~m}$ ). The Köppen climate classification system of the study area corresponds to a Bwk, with an average temperature difference between the warmest and coldest month of $8{ }^{\circ} \mathrm{C}$, while the daily temperature range reaches $13-15{ }^{\circ} \mathrm{C}$, and annual rainfall is $12 \mathrm{~mm}$ with winter regime.

'Thompson Seedless' and 'Redglobe' plants were own-rooted, 20-year-old, drip irrigated (4 $\mathrm{L} \cdot \mathrm{h}^{-1}$ emitters, 3 emitters per plant) and trained to an overhead arbor (parronal or pergola) trellis system. 'Thompson Seedless' vines were planted 3 x $3 \mathrm{~m}$ $(1,111$ plants/ha) on a soil from the Chañar Blanco series (CIREN, 2007), a sandy loam with stone alluvial substrate in $70 \%$ of soil volume, with roots present up to $0.8 \mathrm{~m}$ depth. 'Redglobe' plants were spaced $3 \times 1.5 \mathrm{~m}(2,222$ plants/ha) and planted on a soil corresponding to a clay loam of the Chanchoquín series (CIREN, 2007), with roots present up to $1.2 \mathrm{~m}$ of soil depth.

For both cultivars healthy and uniform plants were selected, grouping by rows to minimize soil and slope differences within the vineyard block. Crop load adjustment and other cultural practices were done according to commercial grower practices. For 'Thompson Seedless', gibberellic acid was applied for berry sizing (3 cluster-directed sprays beginning 2 weeks after anthesis), and vines were trunk girdled (removal of a ring of phloem) at fruit set. Crop load was adjusted each season to 35 clusters per vine.

\section{7-2008 Season}

To establish the relation between $\psi_{\text {stem }}$ and VPD, 'Thompson Seedless' vines were used.

Four treatments were applied using valves: T1 corresponded to vines irrigated at $100 \%$ crop evapotranspiration $\left(\mathrm{ET}_{\mathrm{c}}\right)$ with a threshold for irrigation of $10 \%$ decrease in soil available moisture $(\mathrm{Aw}=$ Field Capacity - Permanent Wilting Point $) ; \mathrm{T} 2$ were vines irrigated simultaneously with $\mathrm{T} 1$ until fruit set and then every other time T1 plants were irrigated; T3 plants were irrigated as T1 until fruit set and then not irrigated up to after harvest; T4 vines were irrigated at 50\% ETc throughout the growing season (50\% water volume compared to $\mathrm{T} 1)$.

The $\mathrm{ET}_{\mathrm{c}}$ was obtained using the Penman-Monteith equation (Allen et al., 1998), calculating potential evapotranspiration $\left(\mathrm{ET}_{\mathrm{o}}\right)$ based on air temperature, solar radiation, wind speed and relative humidity from a weather station (Vantage Pro2, Davis Instruments Corp., USA) and then adjusted using a table grape 'Thompson Seedless' crop coefficients $\left(\mathrm{K}_{\mathrm{c}}\right)$ established by Sellés et al. (2003), 0.2 for vines with shoots $20-60 \mathrm{~cm}, 0.3$ for vines with shoots $60-80$ $\mathrm{cm}, 0.6$ at bloom, 0.8 at $8 \mathrm{~mm}$ berry size, 0.95 at veraison and 0.9 at harvest.

The first irrigation for all treatments occurred after bud break when $8 \mathrm{~mm}$ of $\mathrm{ET}_{\mathrm{c}}$ were lost, corresponding to vines with shoots $10 \mathrm{~cm}$ long. The Aw was $80 \mathrm{~mm}$, estimated for this soil type using the Saxton and Rawls (2006) equation, and then irrigation frequency and time for $\mathrm{T} 1$ were determined from $\mathrm{ET}_{\mathrm{c}}$ lost and replacement of $8 \mathrm{~mm}$. 


\section{Season 2008-2009}

Trials were established on the two table grape cultivars, each with a different soil type.

Trial 1. The same 'Thompson Seedless' vineyard was used in the 2007-2008 season. There were two treatments: T1 corresponded to vines irrigated at $100 \% \mathrm{ET}_{\mathrm{c}}$, using the same criteria as 2007-2008 season (threshold of $10 \%$ decrease of Aw in the root zone); T2 irrigation frequency was determined from the RL obtained from the $\psi_{\text {stem }}$-VPD relationship from previous season, watering when any of the replicates reached that relationship. Irrigation time (IT) for both treatments was calculated as to restore the soil profile to Field Capacity (for the 'Thompson Seedless' soil $\mathrm{FC}=24 \mathrm{~mm}$, according to the equation of Saxton and Rawls (2006) up to $0.8 \mathrm{~m}$ depth. (Table I).

\section{Table I}

Soil physical characteristics for trial 1 (Chañar Blanco series) Características físicas do solo para ensaio 1 (série Chañar Blanco)

\begin{tabular}{cccccc}
\hline $\begin{array}{l}\text { Depth } \\
(\mathrm{m})\end{array}$ & $\begin{array}{c}\text { FC } \\
(\%)\end{array}$ & $\begin{array}{c}\text { PWP } \\
(\%)\end{array}$ & $\begin{array}{c}\text { Gravel } \\
(\%)\end{array}$ & $\begin{array}{c}\text { MBD } \\
\left(\mathrm{g} \cdot \mathrm{cm}^{-3}\right)\end{array}$ & $\begin{array}{c}\text { AW } \\
(\mathrm{mm})\end{array}$ \\
\hline 0.8 & 18.2 & 11.5 & 70 & 1.5 & 24 \\
\hline FC: Field capacity; & PMP: Permanent wilting point; MBD: Matric \\
bulk density; AW: Available water. Adapted from CIREN, 2007.
\end{tabular}

Trial 2. Own-rooted 20-year-old 'Redglobe' plants were used for this trial. Three different treatments were applied. Control treatment (T1) corresponded to plants irrigated to satisfy $100 \%$ Etc, using the same criteria as for 'Thompson Seedless' (every time Aw of the root zone was reduced $10 \%$ ), but with an Aw for this type of soil of $160 \mathrm{~mm}$ (according to the equation of Saxton and Rawls, 2006); T2 were vines irrigated from veraison to harvest every other time compared to T1; and T3 with an irrigation frequency determined by the previously established $\psi_{\text {stem }}$ VPD $\mathrm{RL}$, irrigating vines when any of the replicates reached the RL. Irrigation time (IT) for T2 and T3 was determined in order to replenish Aw at the soil profile (0-1.2 $\mathrm{m}$ depth) to field capacity (Table II). The Field Capacity of the 'Redglobe' soil profile ( 0 to $1.2 \mathrm{~m}$ depth) was $272 \mathrm{~mm}$, according to the equation of Saxton and Rawls (2006).

Table II

Soil physical characteristics for trial 2 (Chanchoquín series). Características físicas do solo para ensaio 2 (série Chanchoquín))

\begin{tabular}{cccccc}
\hline $\begin{array}{l}\text { Depth } \\
(\mathrm{m})\end{array}$ & $\begin{array}{c}\text { FC } \\
(\%)\end{array}$ & $\begin{array}{c}\text { PWP } \\
(\%)\end{array}$ & $\begin{array}{c}\text { Gravel } \\
(\%)\end{array}$ & $\begin{array}{c}\text { MBD } \\
\left(\mathrm{g} \cdot \mathrm{cm}^{-3}\right)\end{array}$ & $\begin{array}{c}\text { AW } \\
(\mathrm{mm})\end{array}$ \\
\hline 0.8 & 18.2 & 11.5 & 70 & 1.5 & 24 \\
\hline
\end{tabular}

\section{Experimental design}

In both seasons, the design of the experiment was a completely randomized block of three adjacent rows each, with three replicates per treatment. The experimental unit was a group of seven adjacent plants within each of the three rows conforming the block, and to minimize border effect only the three central vines in the central row were evaluated, therefore values of each replicate correspond to the mean value of the three middle plants.

\section{Evaluations}

Stem water potential $\left(\psi_{\text {stem }}\right)$. In both seasons stem water potential was evaluated weekly, on one shaded and basal leaf per vine, at solar noon, when water demand was the highest $(13: 30-16: 30 \mathrm{~h}$ in the area according to Gálvez et al., 2010; although measurements were never done after 14:30 hrs). Leaves were bagged with both plastic and aluminium foil at least 90 minutes before measurement. Subsequently the leaf was excised from the vine, and, without removing the bag, $\psi_{\text {stem }}(\mathrm{MPa})$ was measured immediately (within $10 \mathrm{sec}$ ) with a Scholander type pressure chamber, Pump-up model (PMS Instrument Company, Oregon, USA).

Air temperature $\left(\mathrm{T}_{\text {air }} ;{ }^{\circ} \mathrm{C}\right)$ and relative humidity (RH; \%). Temperature and $\mathrm{RH}$ were registered concurrent with $\psi_{\text {stem, using a digital thermo- }}$ hygrometer model AZ 8701 (AZ Instrument Corp, Tai-chung, Taiwan) located in the shade $1 \mathrm{~m}$ above the vine canopy.

Saturation vapor pressure $\left(\mathbf{e}_{\mathbf{s}}\right)$. Determined with temperature and relative humidity values using the Murray equation (1967) (Eq. 1). Partial vapor pressure (e) was obtained using relative humidity and $\mathrm{e}_{\mathrm{s}}$ (Eq. 2). The VPD was obtained by $\mathrm{e}_{\mathrm{s}}-\mathrm{e}(\mathrm{kPa})$ difference.

$$
e_{s}(T)=0.611 \exp \left[\frac{17.27 \mathrm{~T}}{\mathrm{~T}+237.3}\right]
$$

$\mathrm{e}=\mathrm{e}_{\mathrm{s}} * \mathrm{HR} / 100$

Eq. 2

Where:

$$
\begin{aligned}
& \mathrm{e}_{\mathrm{s}}=\text { Saturation vapor pressure }(\mathrm{kPa}) \\
& \mathrm{e}=\text { Partial vapore pressure }(\mathrm{kPa}) \\
& \mathrm{T}=\text { Temperature }\left({ }^{\circ} \mathrm{C}\right)
\end{aligned}
$$

Stomatal conductance $\left(\mathbf{g}_{\mathrm{s}}\right)$. The second season data for gs was collected once a week, between 10 and 11 a.m. (Gálvez et al., 2010). Five measurements were made per plant, using leaves exposed to the sun. Measurements were done with a leaf porometer, model SC-1 (Decagon Devices, Pullman, WA, USA), and expressed in $\mu \mathrm{mol} \cdot \mathrm{cm}^{-2} \cdot \mathrm{s}^{-1}$.

Leaf temperature $\left(\mathbf{T}_{\text {leaf }}\right)$. Jackson et al. (1977) methodology was followed for leaf temperature as a plant water status indicator analysis, because the difference between leaf and air temperature $\left(\mathrm{T}_{\text {leaf }}-\right.$ $\mathrm{T}_{\text {air }}$ ) evaluated at maximum daily temperature can be used as a plant water status indicator, since a positive difference representative of some level of water stress. Measurements were done once a week during the 2008-2009 season, using an infrared thermometer (Cole-Parmer Instrument Co., Illinois, USA), and expressed in ${ }^{\circ} \mathrm{C}$. Five sun exposed leaves per plant 
were measured prior to $\psi_{\text {stem }}$ determination (solar noon).

Harvest date, yield and quality. Harvest was done when grapes reached commercial maturity of minimum $16.5^{\circ}$ Brix, plus $80 \%$ cluster color coverage for 'Redglobe', and cluster weight and commercial berry size of all clusters was recorded. The harvest dates for 'Thompson Seedless' were December $15^{\text {th }}$ and $22^{\text {nd }}$ of 2008 , and for 'Redglobe' were January $15^{\text {th }}, 20^{\text {th }}$ and $26^{\text {th }}$ of 2009 .

Irrigation water use efficiency (WUEi, $\mathbf{k g} \bullet \mathbf{m}^{\mathbf{3}}$ ). Obtained by the ratio between yield $\left(\mathrm{kg} \bullet \mathrm{ha}^{-1}\right)$ and the amount of irrigation water applied during the 2008-2009 season $\left(\mathrm{m}^{3} \bullet \mathrm{ha}^{-1}\right)$, which was measured with pluviometers through out the trial (to corroborate the amount of water applied).

\section{Statistical analysis}

Prior to submitting data to an analysis of variance (ANOVA), assumptions were checked on the error terms, using residual based techniques. AndersonDarling test was used to verify normality and Barlett's test was used to verify homogeneity. When assumptions were not met, original variables were transformed. If assumptions were not possible to comply the non-parametric Friedman test for completely randomized blocks at 5\% significance was used. Regression analysis was used to relate $\psi_{\text {stem }}$ and VPD. Analyses were done using Minitab $^{\circledR}$ software (Minitab Inc, Pennsylvania, USA).

\section{RESULTS AND DISCUSSION}

\section{Reference line (Season 2007-2008)}

During the study period a wide range of VPD was reached, from 1 to $6 \mathrm{kPa}$ (Figure 1), mainly due to relative humidity variation. Regarding stem water potential, plants irrigated at 100\% ETc (T1) presented higher average $\psi_{\text {stem }}$ than other treatments, at any VPD (Table III); $\psi_{\text {stem }}$ values for T1 varied between $0.25 \mathrm{MPa}$ for VPD of $1.2 \mathrm{kPa}$, up to $-0.66 \mathrm{MPa}$ for VPD of $6.0 \mathrm{kPa}$ (Figure 1).

\section{Table III}

Average stem water potential $\left(\psi_{\text {stem }}\right)$ of different treatments on

'Thompson Seedless' vines for two VPD values in 2007-2008.

Potencial hídrico xilemático médio $\left(\psi_{\text {stem }}\right)$ de diferentes tratamentos em 'Thompson Seedless' para dois valores de VPD

\begin{tabular}{lll}
\hline \multirow{2}{*}{ Treatments } & \multicolumn{1}{l}{$\Psi_{\text {stem }}(\mathrm{MPa})$} \\
\cline { 2 - 3 } & VPD 3.0 kPa & VPD 6.0 kPa \\
\hline T1 & $-0,63 \mathrm{a}$ & $-0.66 \mathrm{a}$ \\
T2 & $-0.75 \mathrm{~b}$ & $-0.80 \mathrm{~b}$ \\
T3 & $-0.80 \mathrm{c}$ & $-0.85 \mathrm{c}$ \\
T4 & $-0.90 \mathrm{~d}$ & $-1.00 \mathrm{~d}$
\end{tabular}

Different letters in the same column indicate significant differences according to multiple comparison test of Tukey $(\mathrm{p}<0.05, \mathrm{n}=3)$; $\mathrm{T} 1$ vines irrigated at $100 \% \mathrm{Et}_{\mathrm{c}}$ every time $\mathrm{Aw}$ was reduced $10 \%$; $\mathrm{T} 2$ irrigated the same as T1 until fruit set and then every other time T1; T3 no irrigated from fruit set to after harvest; T4 irrigated at 50\% ETc throughout the growing season.

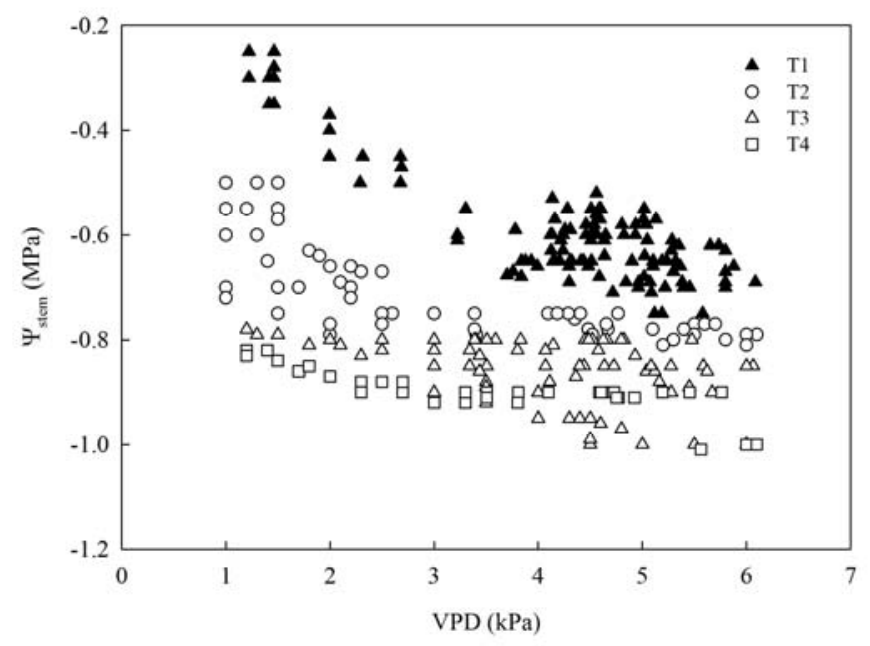

Figure 1. Average stem water potential $\left(\psi_{\text {stem }}\right)$ in function of atmospheric vapor pressure deficit (VPD) for different irrigation treatments between October $17^{\text {th }} 2007$ and January $10^{\text {th }} 2008$; T1 vines irrigated at $100 \%$ Et $_{\mathrm{c}}$ every time Aw was reduced $10 \%$; T2 irrigated the same as T1 until fruit set and then every other time T1; T3 no irrigated from fruit set to after harvest; T4 irrigated at 50\% $\mathrm{ET}_{\mathrm{c}}$ throughout the growing season.

Potencial hídrico xilemático médio $\left(\psi_{\text {stem }}\right)$ em função do déficit de pressão de vapor (VPD) para diferentes tratamentos de irrigação; T1 plantas irrigadas com 100\% de ETc cada vez que Aw (umidade aproveitável) se reduza a 10\%; T2 irrigada igual ao T1 até a frutificação e depois uma vez a cada duas irrigação de T1; T3 sem irrigação entre a frutificação e a colheita; T4 irrigada com $50 \%$ de ET $T_{c}$ durante toda a temporada de crescimento.

The lowest values for $\psi_{\text {stem }}$ were obtained on T4 plants, ranging from $-0.9 \mathrm{MPa}$ for VPD of $3.0 \mathrm{kPa}$, to $-1.0 \mathrm{MPa}$ for VPD of $6.0 \mathrm{kPa}$. Additionally, the $\psi_{\text {stem }}$ for intermediate treatments (T2 and $\mathrm{T} 3$ ) fluctuated between T1 and T4, with T2 values higher than T3 for all VPD values (Figure 1).

The relationship between $\psi_{\text {stem }}$ and VPD was established using T1 plants. The relationship fitted a 
logarithmic function, $\mathrm{y}=-0.2611 \mathrm{Ln}(\mathrm{x})-0.2308$, with high determination coefficient, $\mathrm{R}^{2}=0.85$; $\mathrm{p}<$
0.05 and with $\psi_{\text {stem }}$ values between -0.23 and -0.70 $\mathrm{MPa}$, (Figure 2).

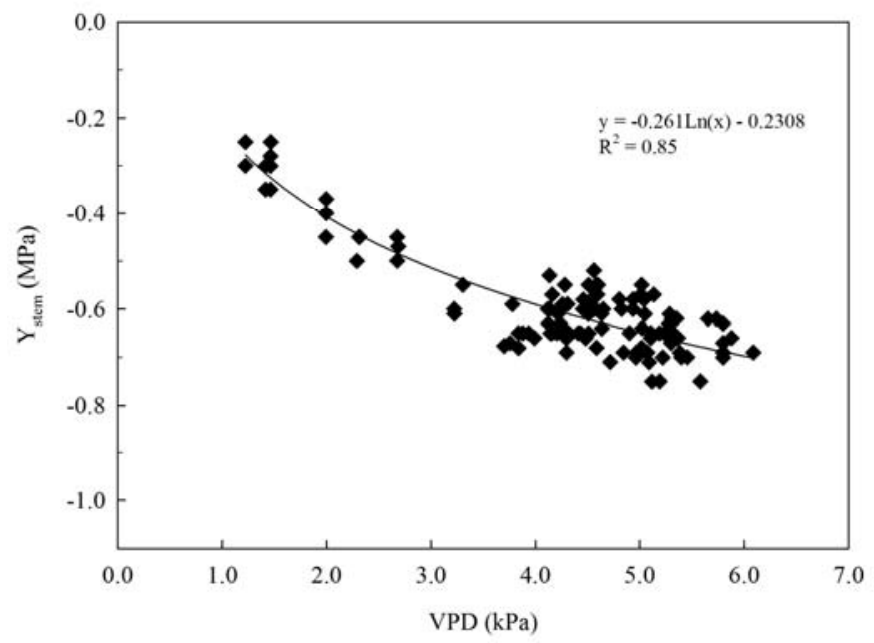

Figure 2. Average stem water potential $\left(\psi_{\text {stem }}\right)$ from fruit set to harvest (between October $17^{\text {th }} 2007$ and January $\left.10^{\text {th }} 2008\right)$ in function of atmospheric vapor pressure deficit (VPD) for grapevines irrigated at $100 \% \mathrm{ET}_{\mathrm{c}}$ every time Aw was reduced $10 \%$.

Potencial hídrico xilemático médio $\left(\psi_{\text {stem }}\right)$ em função do déficit de pressão de vapor (VPD) para videiras irrigadas com $100 \%$ de ETc cada vez que Aw (humidade aproveitável) se reduza a $10 \%$.

\section{Irrigation using RL (Season 2008-2009)}

Throughout the season, $\psi_{\text {stem }}$ in cv. 'Thompson Seedless' readings for both treatments were equal to or higher than those established by RL, between -0.61 and $-0.68 \mathrm{MPa}$ (Figure 3). This was determined during the previous season using the $\psi_{\text {stem }}-$ VPD relationship (Figure 2). For 'Redglobe' the $\psi_{\text {stem }}$ values of all treatments were also equal or higher than the RL, with $\mathrm{T} 3$ closer to the RL than the other treatments (Figure 4).

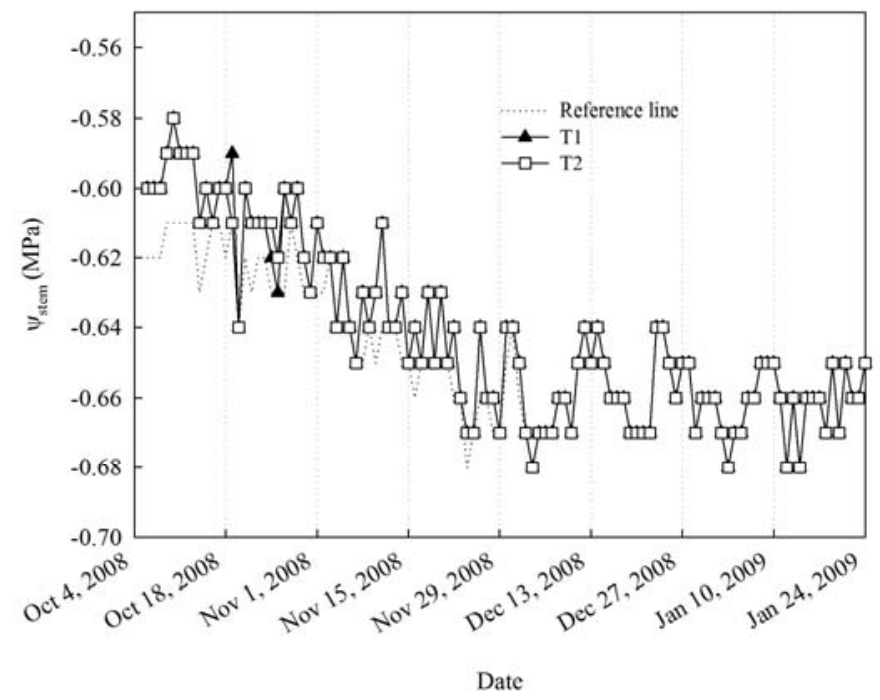

Figure 3. Daily stem water potential $\left(\psi_{\text {stem }}\right)$ evolution throughout the season on cv. 'Thompson Seedless' for different irrigation treatments compared to the reference line obtained previous season from the $\psi_{\text {stem }}$-VPD relationship. T1 irrigated at $100 \% \mathrm{Et}_{\mathrm{c}}$ every time Aw was reduced $10 \%$, and $\mathrm{T} 2$ irrigation based on the RL obtained from the $\psi_{\text {stem }}$ VPD relationship from previous season.

Evolução do potencial hídrico xilemático diário $\left(\psi_{\text {stem }}\right)$ na variedade 'Thompson Seedless' durante a temporada para diferentes tratamentos de

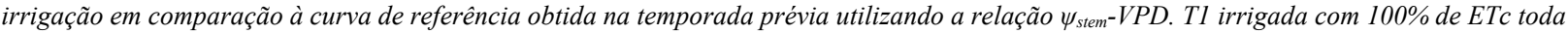
vez que Aw (umidade aproveitável) se reduza a $10 \%$ e T2 irrigada de acordo com a RL obtida na temporada prévia da relação $\psi_{\text {stem-VPD. }}$ 


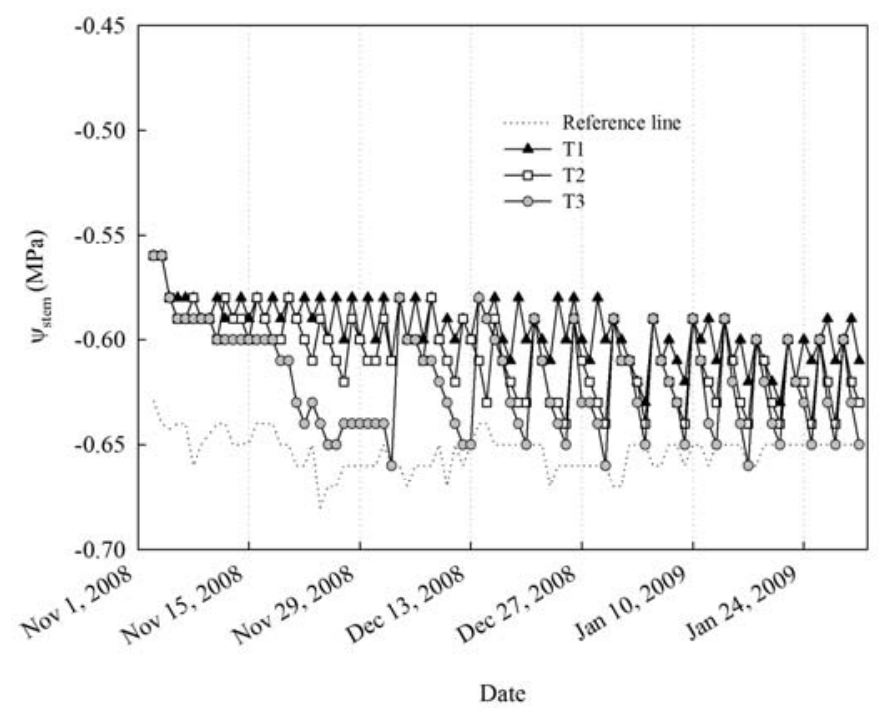

Figure 4. Daily stem water potential $\left(\psi_{\text {stem }}\right)$ evolution throughout the season on cv 'Redglobe' for different irrigation treatments compared to the reference line obtained previous season from the $\psi_{\text {stem }}-\mathrm{VPD}$ relationship. T1 plants irrigated at $100 \% \mathrm{Et}_{\mathrm{c}}$ every time $\mathrm{Aw}$ was reduced $10 \%$; 2 plants irrigated from veraison to harvest every other time T1; T3 plants irrigated according to the RL obtained from the $\psi_{\text {stem }}$-VPD relationship from previous season.

Evolução do potencial hídrico xilemático diário $\left(\psi_{\text {stem }}\right)$ na variedade 'Redglobe' durante a temporada para os diferentes tratamentos de irrigação

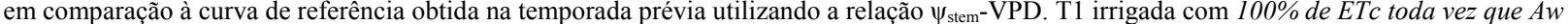
(umidade aproveitável) se reduza a 10\%; T2 irrigada entre a maturação e a colheita uma vez a cada duas irrigações de T1; T3 plantas irrigadas de acordo com a RL obtida na temporada prévia da relação T2 irrigada de acordo com a RL obtida na temporada prévia da relação $\psi_{\text {stem- }}$-VPD.

Stomatal conductance $\left(\mathrm{g}_{\mathrm{s}}\right)$ did not show any significant difference during the season. On 'Thompson Seedless' the lowest $g_{s}$ value of the season corresponded to the beginning of the trial (135 $\left.\mu \mathrm{mol} \cdot \mathrm{cm}^{-2} \cdot \mathrm{s}^{-1}\right)$, and the highest value to the one obtained after harvest $\left(295 \mu \mathrm{mol} \cdot \mathrm{cm}^{-2} \cdot \mathrm{s}^{-1}\right)$ (Figure 5). 'Redglobe' $g_{s}$ values were higher than those for 'Thompson Seedless'; the lowest value was 250 $\mu \mathrm{mol} \cdot \mathrm{cm}^{-2} \cdot \mathrm{s}^{-1}$ mid-season and the highest value was $390 \mu \mathrm{mol} \cdot \mathrm{cm}^{-2} \cdot \mathrm{s}^{-1}$ at the end of the season (Figure 6).

Leaf temperature between treatments did not show differences on 'Thompson Seedless' or 'Redglobe', and it was always lower than air temperature (Figures 5 and 6). Daily leaf and air temperature difference $\left(\mathrm{T}_{\text {leaf }}{ }^{-} \mathrm{T}_{\text {air }}\right)$ was around $-0.5{ }^{\circ} \mathrm{C}$ for 'Thompson
Seedless' (Figure 5) and $-1.0{ }^{\circ} \mathrm{C}$ for 'Redglobe' (Figure 6).

Irrigation scheduling on table grapes using the $\psi_{\text {stem- }}$ VPD relationship caused a decrease of the total irrigation water volume applied during the growing season compared to the vineyard commercial management (T1). For 'Thompson Seedless' the decrease was $6 \%$ (Table IV), while for 'Redglobe' there was larger water saving, reducing water use compared to $\mathrm{T} 1$ by $50 \%$ and $53.8 \%$ for $\mathrm{T} 2$ and $\mathrm{T} 3$, respectively (Table V). Despite the smaller water use, yield and cluster quality were not affected, and irrigation water use efficiency increased on 'Thompson Seedless' from 2.9 to $3.1 \mathrm{~kg} \cdot \mathrm{m}^{-3}$ and on 'Redglobe' from 4.4 to $9.8 \mathrm{~kg} \cdot \mathrm{m}^{-3}$ (Tables IV and V).

Table IV

Yield, irrigation water volume applied and water use efficiency (WUEi) for different irrigation treatments on 'Thompson Seedless' vines in 2007-

$$
2008 \text { season }
$$

Rendimento, volume de água de irrigação aplicado e eficiência no uso da água (EUAr) para diferentes tratamentos de irrigação em videiras

'Thompson Seedless'

\begin{tabular}{cccccc}
\hline Treatments & \multicolumn{2}{c}{ Yield } & \multicolumn{2}{c}{ Applied Water Volume } & $\begin{array}{c}\text { WUEi } \\
\left(\mathrm{kg} \cdot \mathrm{m}^{-3}\right)\end{array}$ \\
\hline $\mathrm{T} 1$ & $\left(\mathrm{~kg} \cdot \mathrm{plant}^{-1}\right)$ & $\left({\left.\mathrm{kg} \cdot \mathrm{ha}^{-1}\right)}\right.$ & $\left(\mathrm{m}^{3} \cdot \mathrm{plant}^{-1}\right)$ & $\left(\mathrm{m}^{3} \cdot \mathrm{ha}^{-1}\right)$ & \\
$\mathrm{T} 2$ & $19.30 \mathrm{a}$ & 21.502 & 6.7 & 7,410 & 2.9 \\
\hline
\end{tabular}

Different letters in the same column indicate significant differences according to multiple comparison test of Tukey $(\mathrm{p}<0.05, \mathrm{n}=3)$. T1 irrigated at $100 \%$ Etc every time Aw was reduced $10 \%$, and T2 irrigation based on the RL obtained from the $\psi_{\text {stem }}-V P D$ relationship from previous season. 
Table V

Yield, irrigation water volume applied and water use efficiency (WUEi) for different irrigation treatments on 'Redglobe' vines Rendimento, volume de água de irrigação aplicado e eficiência no uso da água (EUAr) para diferentes tratamentos de irrigação em videiras

'Redglobe'

\begin{tabular}{cccccc}
\hline \multirow{2}{*}{ Treatments } & \multicolumn{2}{c}{ Yield } & \multicolumn{2}{c}{ Applied Water Volume } & $\begin{array}{c}\text { WUEi } \\
\left(\mathrm{kg} \cdot \mathrm{m}^{-3}\right)\end{array}$ \\
\hline $\mathrm{T} 1$ & $21.0 \mathrm{a}$ & 46,662 & 4.7 & $10,506.6$ & $4.4 \mathrm{a}$ \\
$\mathrm{T} 2$ & $21.2 \mathrm{a}$ & 47,106 & 2.3 & $5,253.3$ & $9.0 \mathrm{~b}$ \\
$\mathrm{~T} 3$ & $21.4 \mathrm{a}$ & 47,551 & 2.2 & $4,853.3$ & $9.8 \mathrm{~b}$ \\
\hline
\end{tabular}

Different letters in the same column indicate significant differences according to multiple comparison test of Tukey $(\mathrm{p}<0.05, \mathrm{n}=3)$. T1 plants irrigated at $100 \% \mathrm{Et}_{\mathrm{c}}$ every time $\mathrm{Aw}$ was reduced $10 \%, \mathrm{~T} 2$ plants irrigated from veraison to harvest every other time T1, and T3 plants irrigated according to the RL obtained from the $\psi_{\text {stem }}-\mathrm{VPD}$ relationship from previous season.
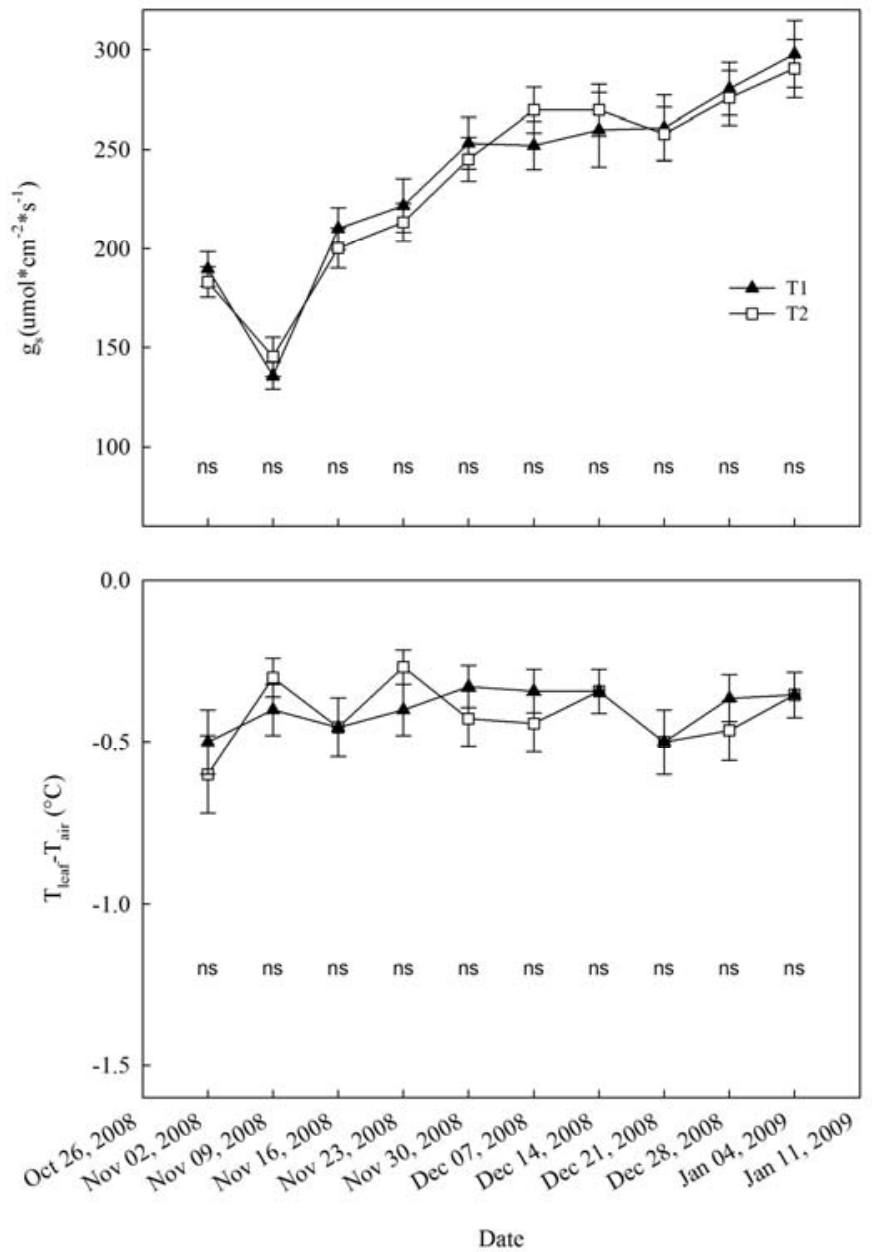

Figure 5. Evolution throughout the season of daily average stomatal conductance $\left(\mathrm{g}_{\mathrm{s}}\right)$ and leaf temperature measured once a week in cv. Thompson Seedless for different irrigation treatments; $\mathrm{T} 1$ irrigated at $100 \% \mathrm{Et}_{\mathrm{c}}$ every time $\mathrm{Aw}$ was reduced $10 \%$, and $\mathrm{T} 2$ irrigation based on the RL obtained from the $\psi_{\text {stem }}$-VPD relationship from previous season. Bars correspond to standard error. ns not significant $\mathrm{p}<0.05$.

Evolução durante a temporada da média da condutância estomática diária (gs) e a temperatura da folha medida semanalmente na variedade de Thompson Seedless para os diferentes tratamentos de irrigação; T1 irrigada com 100\% de ETc toda vez que Aw (humidade aproveitável) se reduza a $10 \%$ e T2 de acordo com a RL obtida na temporada prévia da relação T2 irrigada de acordo com a RL obtida na temporada prévia da

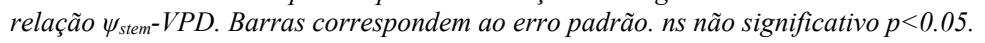

The 'Thompson Seedless' harvest was done on two different dates, with no differences on yield or berry size (berry diameter) for both treatments on any date
(Table VI). The 'Redglobe' yield showed differences among treatments on each harvest date (Table VII), with less fruit obtained from the control treatment 
(T1). Fruit was harvested on three dates, but on the earlier harvest day no fruit was obtained from the control treatment because color development was delayed five days compared to the other treatments.

Table VI

Export quality-fruit yield per plant and berry diameter of cv. Thompson Seedless for different irrigation treatments Rendimento de fruta de exportação e diâmetro de bagas da variedade 'Thompson Seedless' para diferentes tratamentos de irrigação

\begin{tabular}{|c|c|c|c|}
\hline \multirow[b]{2}{*}{ Treatments } & \multicolumn{2}{|c|}{ Yield } & \multirow{2}{*}{$\begin{array}{c}\text { Berry } \\
\text { Diameter } \\
(\mathrm{mm})\end{array}$} \\
\hline & \multicolumn{2}{|c|}{$\left(\mathrm{kg} \cdot\right.$ plant $\left.^{-1}\right)$} & \\
\hline $\mathrm{T} 1$ & $5.5 \mathrm{a}$ & $13.8 \mathrm{a}$ & $18.3 \mathrm{a}$ \\
\hline $\mathrm{T} 2$ & $5.5 \mathrm{a}$ & $13.8 \mathrm{a}$ & $18.5 \mathrm{a}$ \\
\hline
\end{tabular}

Different letters in the same column indicate significant differences according to multiple comparison test of Tukey $(\mathrm{p}<0.05, \mathrm{n}=3)$. T1 irrigated at $100 \% \mathrm{Et}_{\mathrm{c}}$ every time Aw was reduced $10 \%$, and $\mathrm{T} 2$ irrigation based on the RL obtained from the $\psi_{\text {stem }}-\mathrm{VPD}$ relationship from previous season.
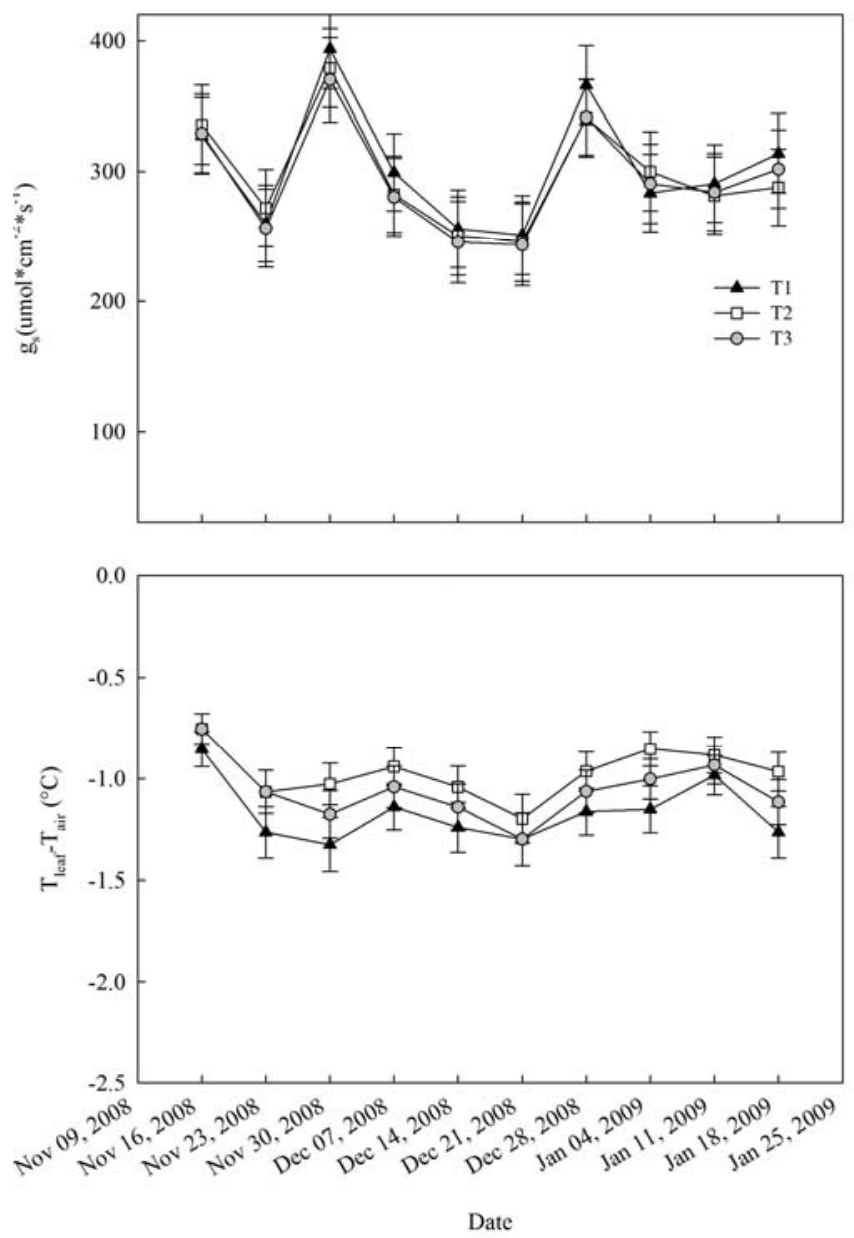

Figure 6. Evolution throughout the season of daily average stomatal conductance $\left(\mathrm{g}_{\mathrm{s}}\right)$ and leaf temperature measured once a week in cv. Redglobe for different irrigation treatments; $\mathrm{T} 1$ plants irrigated at $100 \% \mathrm{Et}_{\mathrm{c}}$ every time $\mathrm{Aw}$ was reduced $10 \%$, T2 plants irrigated from veraison to harvest every other time T1, and T3 plants irrigated according to the RL obtained from the $\psi_{\text {stem }}$-VPD relationship from previous season. Bars correspond to standard error. ns: not significant $\mathrm{p}<0.05$.

Evolução durante a temporada da média da condutância estomática diária (gs) e a temperatura da folha medida semanalmente na variedade de Redglobe para os diferentes tratamentos de irrigação; T1 irrigada com $100 \%$ de ETc cada vez que Aw (umidade aproveitável) se reduza a 10\%, T2 irrigada entre a maturação e a colheita uma vez a cada duas irrigações de T1, e T3 plantas irrigadas de acordo com a RL obtida na temporada prévia da relação T2 irrigada de acordo com a RL obtida na temporada prévia da relação $\psi_{\text {stem- }}$ VPD.Barras correspondem ao erro padrão. ns: não significativo $p<0.05$ 


\section{DISCUSSION}

In general, $\psi_{\text {stem }}$ values for no water stress-grapes are similar (Patakas et al., 2005; Williams and Trout, 2005; Williams and Baeza, 2007) and higher than -0.7 MPa (Figure 1). However, Sellés et al. (2002) and Deloire et al. (2004) categorized optimal grapevine hydric condition by more negative $\psi_{\text {stem }}$ values, although lower than -1.0 MPa. The difference could be explained by evaluation methodology and/or operator differences. Regarding this, Goldhamer and Fereres (2001) working on almond trees showed a 0.2 $\mathrm{MPa}$ variation due only to the individual evaluating water potential. On the other hand, the difference would not be result of the pressure chamber, since Gálvez et al. (2011) on table grapes proved there is no difference on stem water potential evaluated with a Pum-up versus a traditional Scholander model.

\section{Table VII}

Export quality-fruit yield per plant and berry diameter of cv. 'Redglobe' for different irrigation treatments Rendimento de fruta de exportação e diâmetro dos bagos da variedade 'Redglobe' para diferentes tratamentos de irrigação

\begin{tabular}{ccccc}
\hline & \multicolumn{3}{c}{ Yield } & $\begin{array}{c}\text { Berry } \\
\text { diameter } \\
\text { Treatments }\end{array}$ \\
\cline { 2 - 4 } & 15 Jan. 2009 & $\begin{array}{c}\text { 20 Jan. 2009 } \\
\left(\mathrm{kg} \mathrm{plant}^{-1}\right)\end{array}$ & 26 Jan. 2009 & \\
\hline T1 & $0.0 \mathrm{a}$ & $4.5 \mathrm{a}$ & $16.5 \mathrm{~b}$ & $26.5 \mathrm{a}$ \\
T2 & $1.7 \mathrm{~b}$ & $8.5 \mathrm{~b}$ & $11.0 \mathrm{a}$ & $26.3 \mathrm{a}$ \\
T3 & $1.7 \mathrm{~b}$ & $8.8 \mathrm{~b}$ & $10.9 \mathrm{a}$ & $26.0 \mathrm{a}$ \\
\hline
\end{tabular}

Different letters in the same column indicate significant differences according to multiple comparison test of Tukey $(\mathrm{p}<0.05, \mathrm{n}=3)$. T1 plants irrigated at $100 \% \mathrm{Et}_{\mathrm{c}}$ every time Aw was reduced $10 \%$, T2 plants irrigated from veraison to harvest every other time T1, and T3 plants irrigated according to the RL obtained from the $\psi_{\text {stem }}$-VPD relationship from previous season.

The relation between VPD and $\psi_{\text {stem }}$ shows that, under the studied VPD range (1 to $6 \mathrm{kPa}$; Figure 2$)$, at higher VPD the $\psi_{\text {stem }}$ decreases. This relationship could be explained by the weather influence on $\psi_{\text {stem }}$ readings of plant water status of fully irrigated vines. Similar results are found in the literature for grapevines (Pire et al. 1988; Choné et al., 2001; Kaiser et al., 2004; Patakas et al., 2005; Williams and Trout, 2005; Williams and Baeza, 2007) and other fruit trees such as peach (Garnier and Berger, 1985), walnut (Cohen, 1994) and avocado (Ferreira et al., 2007). However, instead of the linear relationship found by Williams and Baeza (2007), who worked with four varieties and five different sites, the relationship on the present study fitted a logarithmic function. This discrepancy could be explained by the single site and cultivar of the present study, as well as larger evaluation data and the VPD range used. The relationship obtained was similar to the one found by Ferreira et al. (2007) on avocado trees irrigated at $100 \%$ ET.

On treatments where less water was applied (T3 and T4) there was no relation between VPD and $\psi_{\text {stem, }}$ probably due to the greater influence of soil and plant water deficit as previously shown by Williams and Baeza (2007). This uneven behavior could be explained by the maximum difference between water absorbed by roots and transpired by leaves, with over $4 \mathrm{kPa}$ of VPD on most evaluations (Kaiser et al., 2004), since the root-leaf water difference shows a water deficit produced by weather, independent of soil water content. Studies on grapevines have shown an increase in abscisic acid with high VPD, thus there would exist a large sensibility to close stomata in response to VPD variation (Lovisolo et al., 2002).
During the second season irrigation schedules based on $\psi_{\text {stem }}$ did not produce vine water stress on this treatment, showing $\psi_{\text {stem }}$ values always above the RL (Figures 3 and 4), and similar to those values found for grapevines irrigated at 100\% ET (Pire et al. 1988; Choné et al., 2001; Kaiser et al., 2004; Patakas et al., 2005; Williams and Trout, 2005; Williams and Baeza, 2007). This indicates that neither the yield potential nor the fruit development of plants with less water was affected, since berry size (measured as equatorial diameter) did not change (Table III, IV, VI and VII).

Irrigation scheduling for T2, on 'Thompson Seedless' was established by $\psi_{\text {stem }}$ daily values contrasted with the reference line (RL) (Figure 3), displaying the necessity of daily irrigation (data not shown), probably due to the low water holding capacity of the Chañar Blanco soil series (CIREN, 2007). On the contrary, 'Redglobe' showed $\psi_{\text {stem }}$ values very distant from the threshold, and their decrease on the more restricted irrigation treatment (T3) was slow (Figure 4), allowing an irrigation frequency on the fruit setveraison period of 40 days (data not shown).

Stomatal conductance $\left(\mathrm{g}_{\mathrm{s}}\right)$ did not change among treatments (Figures 5 and 6) and was similar to data presented in literature for grapevines irrigated at $100 \%$ ET $_{\mathrm{c}}$ (Medrano et al., 2003; Schultz, 2003; Cifre et al., 2005; Patakas et al., 2005; Sousa et al., 2006; Williams and Baeza, 2007; Olivo et al., 2009). Additionally, Tosso and Torres (1986) postulated that water status influences $\mathrm{g}_{\mathrm{s}}$, finding that for many species there is a water potential threshold value -for grapevines -1,3 $\mathrm{MPa}$ - below which $\mathrm{g}_{\mathrm{s}}$ gradually decreases until total stomata closure. 
For all treatments of the 2008-2009 season on both cultivars, leaf temperature never surpassed air temperature (Figures 5 and 6), corroborating that vines were never stressed during the study period.

The use of $\psi_{\text {stem }}$ as indicator for irrigation scheduling allowed for better water use, totaling from bud break to harvest $6,923 \mathrm{~m}^{3} \cdot \mathrm{ha}^{-1}$ for 'Thompson Seedless' and $4,853.3 \mathrm{~m}^{3} \cdot \mathrm{ha}^{-1}$ for 'Redglobe'. This represents a $6 \%$ and $43.1 \%$ water savings, respectively, compared to T1 (Table IV and V). The difference can be explained mainly by different canopy size of both cultivars, $80 \%$ shaded area on 'Thompson Seedless' and 70\% on 'Redglobe' (data not shown); and by the different soil types of the trials. The available water of the 'Thompson Seedless' trial soil is low (24 mm), generating daily irrigation frequency; while the soil in the 'Redglobe' trial has superior water availability (272 $\mathrm{mm}$ ), allowing for T3 an spaced irrigation frequency at the beginning of the trial (from fruit set to veraison) that determined only one irrigation event on this period (data not shown).

Applied water volumes were similar to those used in other parts of the world with similar soil and climate, such as Murcia, Spain; where annual irrigation water volume is around $6,000 \mathrm{~m}^{3} \cdot \mathrm{ha}^{-1}$ or the San Joaquin Valley, California, USA where 5,888 to $7,112 \mathrm{~m}^{3} \cdot \mathrm{ha}^{-1}$ are applied each year depending on canopy size (Mendoza, 2005). Additionally, Winkler (1965) states that grapevines require $5,551 \mathrm{~m}^{3} \cdot \mathrm{ha}^{-1} \cdot \mathrm{year}^{-1}$ under desert climate conditions in order to obtain a good yield.

In Chile, Sellés et al. (2003) working on 'Thompson Seedless' in a temperate region used $5,438 \mathrm{~m}^{3} \cdot \mathrm{ha}^{-}$ ${ }^{1}$.year ${ }^{-1}$ obtaining a good yield $(17 \mathrm{~kg}$ export quality fruit per plant). The difference in applied water volume is because irrigation scheduling by $\psi_{\text {stem }}$ VPD relationship, a tool of easy and cheap implementation allows adjusting irrigation frequency but no irrigation amount, therefore larger water savings are possible by complementing $\psi_{\text {stem }}$ VPD reference line with rootzone soil water content measurements, such as those obtained by capacitance probes which allow to adjust the irrigation depth.

The decrease in applied water compared to commercial irrigation treatment (T1) without changes in yield, caused WUEi increase mainly on 'Redglobe', with a WUEi value of $9.8 \mathrm{~kg} \cdot \mathrm{m}^{-3}$ (Table V). Similar results were found by Mendoza (2005) on table grapes irrigated at $80 \%$ ETc, without yield effects. For 'Thompson Seedless' the WUEi was 3.1 $\mathrm{kg} \cdot \mathrm{m}^{-3}$ (Table IV), similar to Navarrete (2006) values on 'Crimson Seedless'. Quality was again not affected when smaller irrigation water volumes were applied, in agreement with findings of Sellés et al. (2003) on 'Thompson Seedless' and Mendoza (2005) on 'Superior Seedless'.

Regarding harvest date, with 'Redglobe' there was a significant change in fruit ripening, due to better color development that allowed harvesting five days earlier. Goldhamer and Fereres (2001) concluded that reducing applied water on almond trees hastens ripening. Similar results were obtained by Sélles et al. (2003), and by Mendoza (2005) on table grapes.

The results of this research show the commercial feasibility of using $\psi_{\text {stem }}$ as an irrigation schedule criteria for table grapes, in agreement with results found on almond (Naor, 2006; Shakel et al., 1998) and prune tree (Naor, 2006; Shakel et al., 2000). Thus, implementing the use of the $\psi_{\text {stem }}$ VPD generates a powerful tool for irrigation management monitoring, which has been corroborated by Shackel (2011) on prune trees. However, considering the plant an intermediary between demand and water source, water status is highly dynamic, making its characterization difficult (Mendoza, 2005).

\section{CONCLUSIONS}

The $\psi_{\text {stem }}$ variation on 'Thompson Seedless' vines irrigated with no water limitation between fruit set and harvest is explained $85 \%$ by VPD. According to the obtained regression, estimated $\psi_{\text {stem values for }}$ VPD between 1 and $6 \mathrm{kPa}$, on not water-limited vines, is -0.23 and $-0.70 \mathrm{MPa}$, respectively.

Using the regression lines obtained in this work allows to schedule 'Thompson Seedless' and 'Redglobe' irrigation, with the potential of increasing water use efficiency without negatively affecting fruit yield and quality. Additionally, using this regression to schedule irrigation allows advancing 'Redglobe' harvest date.

\section{REFERENCES}

Allen R., Pereira L., Raes D., Smith M., 1998. Crop evapotranspiration. Guidelines for computing crop water requirements. FAO irrigation and drainage paper $\mathrm{n}^{\circ} 56.300 \mathrm{p}$.

Choné X., Van Leeuwen C., Dubourdieu D., Pierre J., 2001. Stem water potential is a sensitive indicator of grapevine water status. Ann. Bot., 87, 477-483.

Cifre J., Bota J., Escalona J., Medrano H., Flexas J., 2005. Physiological tools for irrigation scheduling in grapevine (Vitis vinifera L.) an open gate to improve water-use efficiency. Agric. Ecosyst. Environ., 106, 159-170.

CIREN, 2007. Estudio Agrológico Valle de Copiapó y Valle del Huasco. Publicación 135. 126 p.

Cohen M., 1994. Funcionamiento hídrico y producción frutal del nogal en zonas semiáridas: aplicación al manejo del riego. 298 p. Tesis Dr. Ing. Agr. Lleida, Escola Técnica Superior D’Enginyeria Agraria, Universitat de Lleida.

Deloire A., Carbonneau A., Wang Z. Ojeda H., 2004. Vine and water a short review. J. Int. Sci. Vigne Vin, 38, 1-13.

Ferreira R., Sellés G., Maldonado P., Celedón J., Gil P., 2007. Efecto del clima, de las características de la hoja y de la metodología de medición del potencial hídrico xilemático en palto (Persea americana Mill.). Agr. Tec., 67, 182-188.

Gálvez R., Callejas R., Reginato G., 2010. Comparación de tres indicadores fisiologicos del estado hídrico en vid de mesa. $\mathrm{p}$ 27. In: $61^{\circ}$ Congreso Agronómico de Chile. $11^{\circ}$ Congreso de la sociedad chilena de fruticultura. 56th ISTH Annual Meeting.

Gálvez R., Callejas R., Reginato G., 2011. Comparación de la cámara de presión tipo Scholander modelo Pump-up respecto a la 
cámara de presión tradicional en vides de mesa. Idesia, 29, 175179.

Garnier E., Berger A., 1985. Testing water potential in peach trees as an indicator of water stress. J. Hort. Sci., 60, 47-56.

Grimes D., Williams L., 1990. Irrigation effects on plant water relations and productivity of Thompson seedless grapevine. Crop Sci., 30, 225-260.

Goldhamer D., Fereres E., 2001. Simplified tree water status measurement of stem water potential. Calif. Agr., 55, 32-37.

Howell T., Meron M., 2007. Irrigation scheduling. In: Microirrigation for crop production. Design, Operation, and Management. $2^{\text {nd }}$ edition. 61-130. Lamm F., Ayars J., Nakayama F. (eds.). Elsevier, The Netherlands.

Jackson R., Reginato R., Idso B., 1977. Wheat canopy temperature: A practical tool for evaluating water requirements. Water Resour., 13, 651-656.

Jones H., 2004. Irrigation scheduling:advantages and pitfalls of plant-based methods. J. Exp. Bot., 55, 2427-2436.

Kaiser R.M., Cavagnaro J. B., Rios M., 2004 Response of Argentinian and European cultivars of Vitis vinifera L. to water stress: II Water relations. Acta Hortic., 646, 47-54.

Lovisolo C., Hartung W., Schubert A, 2002. Whole-plant hydraulic conductance and root-to-shoot flow of abscisic acid are independently affected by water stress in grapevines. Funct. Plant Biol., 29, 1349-1356.

Marsal J., Mata M., Del Campo J., Arbones A., Vallverdú X., Girona J., Olivo N., 2008. Evaluation of partial root-zone drying for potential field use as a deficit irrigation technique in commercial vineyards according to two different pipeline layouts. Irrigation Sci., 26, 347-356.

McCutchan H., Shackel K., 1992. Stem water potential as a sensitive indicator of water stress in prune trees. J. Am. Soc. Hortic. Sci., 117, 607-611.

Medrano H., Escalona J.M., Cifre J., Bota J., Flexas J., 2003. A ten-year study on the physiology of two Spanish grapevine cultivars under field conditions: effects of water availability from leaf photosynthesis to grape yield and quality. Funct. Plant Biol., 30, 607-619.

Mendoza J. 2005. Riego de precisión en Vitis vinifera L. cv. Superior Seedless, monitorizado con sondas de capacitivas FDR. 161 p. Tesis Doctoral, Universidad Politécnica de Cartagena.

Murray F., 1967. On the computation of saturation vapor pressure. J. Appl. Meteorol., 6, 203-204.

Naor A., 1998. Relations between leaf and stem water potentials and stomatal conductance in three field-grown woody. J. Hortic. Sci. Biotech., 73, 431-436.

Naor A., 2000. Midday stem water potential as a plant water stress indicator for irrigation scheduling in fruit trees. Acta Hortic., 537, 447-454.

Naor A., 2006. Irrigation scheduling and evaluation of tree water status in deciduous orchard. Hortic. Rev., 32, 111-165.

Navarrete P., 2006. Efecto de la disponibilidad de agua del suelo en el comportamiento estomático, fotosíntesis y transpiración en vid de mesa variedad Crimson Seedless. 29 p. Memoria Ingeniero Agrónomo, Facultad de Ciencias Agronómicas, Universidad de Chile.

Olivo N., Girona J., Marsal J., 2009. Seasonal sensitivity of stem water potential to vapour pressure deficit in grapevine. Irrigation Sci., 27, 175-182.

Patakas A., Noitsakis B., Chouzouri A., 2005. Optimization of irrigation water use in grapevines using the relationship between transpiration and plant water status. Agric. Ecosyst. Environ. 106, 253-259.
Pire R., De Pire M., Tortolero E., De Fréitez Y., 1988. El riego de la vid (Vitis vinifera L.) en el tocuyo, estado Lara. II Relaciones hídricas. Agronomía Tropical, 38, 155-171.

Rosati A., Metcalf S., Buchner R., Fulton A., Lampinen B., 2006. Tree water status and gas exchange in walnut under drought, high temperature and vapour pressure deficit. J. Hortic. Sci. Biotech., 81, 415-420

Saxton K., Rawls W., 2006. Soil water characteristics estimates by texture and organic matter for hydrologic solutions. Soil Sci. Soc. Am. J., 70, 1569-1578.

Sellés G., Ferreira R., Contreras G., Ahumada R., Valenzuela J., Bravo R., 2003. Manejo de riego por goteo en uva de mesa cv. Thompson Seedless cultivado en suelos de textura fina. Agr. Tec., 63, 180-192.

Sellés G., Ferreira R., Maldonado P., 2002. Cámara de presión: instrumento para controlar el riego a través de mediciones del estado hídrico de las plantas. Aconex, 76, 18-26.

Shakel K., 2007. Water relations of woody perennial plant species. J. Int. Sci. Vigne Vin, 41, 121-129.

Shakel K., 2011. A Plant-based approach to deficit irrigation in trees and vines. Hortscience, 42, 173-177.

Sackel K., Ahmadi H., Biasi W., Buchner R., Goldhamer D., Gurusinghe S., Hasey J., Kester D., Krueger B., Lampinen B., McGourty G., Micke W., Mitcham E., Olson B., Pelletrau K., Philips H. Ramos D., Schwankl L., Sibbett S., Snyder R., Southwick S., Stevenson M., Thorpe M., Weinbaum S., Yeager J., 1997. Plant water status as an index of irrigation need in deciduous fruit trees. HortTechnology, 7, 23-29.

Shakel K., Gurusinghe S., Kester D., Micke W., 1998. Water stress responses of almond (Prunus dulcis (Mill)). Acta Hortic., 470, 309316.

Shakel K., Lampinen B., Southwick S., Goldhamer D., Olson W., Sibbett S., Keueger W., Yeager J., 2000. Deficit irrigation in prunes: Maintaining productivity with less water. HortScience, 35, 30-33.

Schultz H., 2003. Differences in hydraulic architecture account for near-isohydric and anisohydric behaviour of two Weld-grown Vitis vinifera L. cultivars during drought. Plant Cell Environ., 26, 13931405.

Smart R., 1974. Aspects of water relations of the grapevine (Vitis vinifera). Am. J. Enol. Vitic., 25, 84-91.

Sousa T., Oliveira M., Pereira J., 2006. Physiological indicators of plant water status of irrigated and non-irrigated grapevines grown in a low rainfall area of Portugal. Plant Soil, 282, 127-134.

Tosso J., Torres J., 1986. Relaciones hidricas de la vid, bajo diferentes niveles de riego, usando goteo, aspersion y surcos. II. Efecto sobre el crecimiento vegetativo y la produccion. Agricultura Tecnica, 46, 283-289.

Van Zyl J., 1987. Diurnal variation in grapevine water stress as a function of changing soil water status and meteorological conditions. S. Afr. J. Enol. Vitic., 8, 45-52.

Williams L., Araujo F., 2002. Correlations among predawn leaf, midday leaf, and midday stem water potential and their correlations with other measures of soil and plant water status in Vitis vinifera. $\mathrm{J}$ Am. Soc. Hortic. Sci., 127, 448-454.

Williams L., Baeza P., 2007. Relations among ambient temperature and vapor pressure deficit and leaf and stem water potentials of fully irrigated, field-grown grapevines. Am. J. Enol. Vitic., 58, 173181.

Williams L., Trout T., 2005. Relationships among vine-and soilbased measures of water status in a Thompson seedless vineyard in response high-frecuency drip irrigation. Am. J. Enol. Vitic., 56, 357-366.

Winkler A., 1965. La poda.. In: Winkler. Viticultura. 301-361. Compañía Editorial Continental, México D.F. 